DOI: $10.38035 /$ JEMSI

Received: 6 Agustus 2020, Revised: 25 Agustus 2020, Publish: 15 September 2020

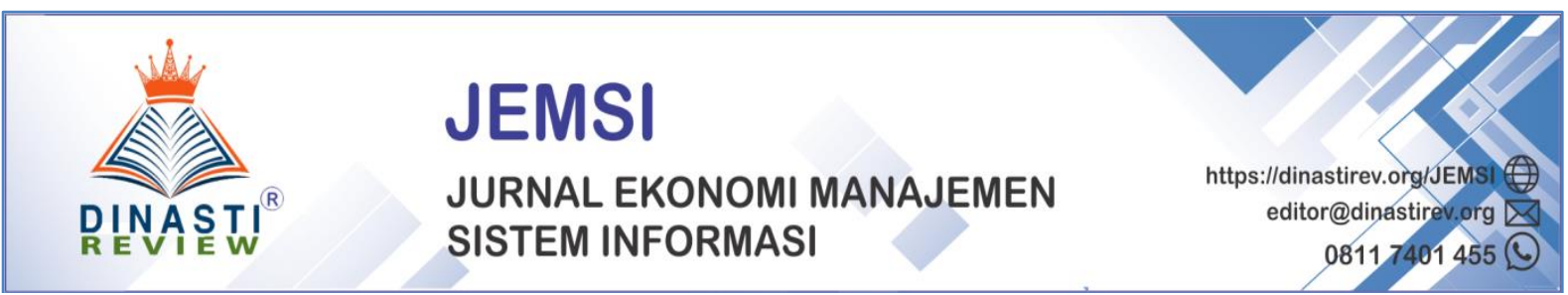

\title{
PERAN AGENCY COST SEBAGAI VARIABEL INTERVENING DARI PENGARUH MEKANISME CORPORATE GOVERNANCE DAN UKURAN PERUSAHAAN TERHADAP KINERJA KEUANGAN
}

\author{
Yamasitha \\ Fakultas Ekonomi dan Bisnis Universitas Putra Indonesia "YPTK" Padang, Indonesia, \\ yamasithasieo@gmail.com
}

\section{Corresponding Author: First Author}

Abstrak: Penelitian ini bertujuan untuk mengetahui bagaimanakah pengaruh Mekanisme Corporate Governance dan Ukuran Perusahaan terhadap kinerja keuangan melalui Agency Cost sebagai variabel Intervening pada perusahaan Manufaktur yang terdaftar di Bursa Efek Indonesia. Sampel pada penelitian ini diambil dengan metode purposive sampling pada perusahaan manufaktur yang terdaftar di Bursa Efek Indonesia dengan periode penelitian selama 5 tahun dari tahun 2014-2018. Pengumpulan data bersumber atau berasal dari Bursa Efek Indonesia (BEI). Website perusahaan (www.idx.co.id.). Hasil penelitian menunjukkan bahwa variabel independen mekanisme corporate goverance berpengaruh negatif terhadap biaya agensi, dan ukuran perusahaan berpengaruh negatif terhadap biaya agensi. Variabel independen Mekanisme Corporate Governance memiliki efek negatif pada kinerja perusahaan dan Mekanisme Corporate Governance memiliki efek tidak langsung negatif pada kinerja perusahaan dengan biaya agensi. Variabel independen ukuran perusahaan tidak berpengaruh positif pada kinerja perusahaan dan ukuran perusahaan memiliki efek tidak langsung negatif pada kinerja perusahaan dengan biaya agensi. Biaya agensi tidak berpengaruh negatif pada kinerja perusahaan.

Kata kunci: Mekanisme Corporate Governance, Ukuran Perusahaan, Kinerja Keuangan dan Agency Cost

\section{PENDAHULUAN}

Sebuah perusahaan didirikan untuk meningkatkan kekayaan pemilik perusahaan atau pemegang saham. Sehingga banyak perusahaan yang bertujuan memaksimalkan nilai perusahaannya hingga dapat mengundang investor untuk berinvestasi pada perusahaan tersebut.

Tujuan utama perusahaan adalah meningkatkan kinerja perusahaan melalui peningkatan kemakmuran politik para pemegang saham. Manajer juga memiliki dorongan untuk mengejar kepentingan pribadi mereka. Bahkan tidak tertutup kemungkinan para manajer melakukan investasi tersebut tidak dapat memaksimalkan nilai pemegang saham (Dewi Ernawati dan Dini Widiyati, 2015). Adanya dewan komisaris indenpenden dapat melakukan pengawasa secara lebih baik terhadap manajemen, Sehingga dapat mengurangi kecurangan dalam menyajikan laporan keuangan. Salah satu ukuran kinerja perusahaan adalah Return On Asset 
( ROA ). ROA dianggap lebih mempresentasikan kepentingan pemegang saham. Nilai ROA yang semakin besar menunjukan kinerja perusahaan yang semakin baik. Para investor menyukai perusahaan yang profitable dikarenakan tingkat pengembalian yang tinggi. Perusahaan dengan kinerja keuangan yang baik akan menghasilkan laba yang maksimal sehingga memiliki tingkat pengembalian investasi yang tinggi (Sudana, 2011:23).

Dalam hal kinerja, perusahaan juga harus memperhatika bentuk dari corporate governance. Contoh kasus tentang good corporate governance oleh PT Freeport Indonesia pada tahun 2017. Permasalahan yang terjadi bermulai dari adanya ketidak sesuaian gaji dan upah para pekerja indonesia yang bila dibandingkan dengan tenaga kerja dari negara lain yang sama levelnya sangat berbeda jauh.gaji perkerja Freeport hanya sebatas upah minimum regional (UMR). Meski dikatakan tidak melanggar hukum, namun gaji yang diberikan tersebut jauh dari apa yang diberikan pekerja, pekerja diperusahaan tambang asal amerika serikat (AS) tersebut sangat tidak merata antara pekerja lokal asli paupa denga pekerja asing. Dan ironisnya, para pekerja lokal umumnya dipekerjakan di level paling bawah, lain halnya dengan pekerja asing.

Hal lain yang jadi perhatian didalam perusahaan adalah terdapatnya beberapa fungsi, antara lain fungsi pengelolaan dan fungsi kepemilikan. Pemisahan fungsi pengelolaan dan fungsi kepemilikan sangat rentan dengan agency conflict (konflik kepentingan). Masalah ini terjadi karena akibat dari pemisahan fungsi sebagai pemilik dan pengelola perusahaan. Jika persentase saham yang dimiliki oleh manajer sedikit, maka besar kemungkinan akan terjadi permasalahan keagenan. Dimana manajer akan melakukan tindakan untuk menguntungkan diri mereka sendiri.

Masalah keagenan dapat menimbulkan biaya agensi (agency cost), yaitu seperti pemberian uang bonus yang layak kepada pihak manajemen serta biaya yang akan dikeluarkan terhadap pengawasan yang dilakukan untuk mencegah terjadinya kerugian. Agency cost juga dapat diartikan sebagai penggunaan aliran kas untuk pengeluaran yang tidak penting yang dilakukan oleh manajer atas free cash flow (arus kas yang tersedia untuk diskresioner yang digunakan manajemen).

Berdasarkan fenomena ,teori dan penelitian terdahulu yang telah disampaikan, peneliti termotivasi untuk meneliti Peran Agency Cost Sebagai Variabel Intervening Dari Pengaruh Mekanisme Corporate Governance Dan Ukuran Perusahaan Terhadap Kinerja Keuangan

KAJIAN PUSTAKA

Signaling theory

Signaling theory juga sering digunakan untuk menjelaskan tentang peranan good corporate governance.

\section{Agency Cost}

Teori keagenan membahas hubungan antara agent dan principal. Dimana agent adalah manajemen pengelola perusahaan, sedangkan principal adalah pemegang saham. Agent dan principal tersebut diikuti oleh suatu kontrak yang menyatakan hak dan kewajiban masingmasing. Principal memberikan fasilitas dan dana untuk menjalankan perusahaan. Teori keagenan ini timbul karena adanya asymmetric information antara prinsipal dan agen, 
asymmetric interest antara prinsipal dan agen serta karena adanya unobservable behavior atau bounded rationality. Dengan adanya ketiga hal tersebut maka antara prinsipal dan agen akan mengutamakan kesejahteraan masing - masing. Agen akan berusaha memaksimalkan kemakmurannya dengan mengharapkan kompensasi yang besar. Sedangkan pemegang saham akan memaksimalkan kesejahteraan melalui pembagian deviden yang maksimal.

\section{Trade-off theory}

Teori trade off merupakan gagasan bahwa perusahaan memilih beberapa banyak pembiayaan hutang dan berapa banyak dana ekuitas yang digunakan dengan menyeimbangkan biaya dan manfaat. Tujuan penting dari teori ini adalah untuk menjelaskan fakta bahwa perusahaan biasanya dibiayai sebagian dengan utang dan sebagian lagi dengan ekuitas. Perusahaan mendasarkan keputusan pendanaan pada struktur modal yang optimal dibentuk dengan menyeimbangkan manfaat dari penghematan pajak atas penggunaan utang terhadap biaya kebangkrutan.

\section{Kinerja Keuangan}

Menurut Wibowo (2014:7), "kinerja berasal dari pengertian performance. Ada pula yang memberikan pengertian performnace sebagai hasil kerja atau prestasi kerja. Namun, sebenarnya kinerja mempunyai makna luas, bukan hanya hasil kerja, tetapi bagaimana proses pekerjaan berlangsung". Kinerja perusahaan (organizational performance) merupakan seberapa efisien dan efektif sebuah perusahaan atau seberapa baik perusahaan itu mencapai tujuannya. istilah kinerja atau performance sering dikaitkan dengan kondisi keuangan perusahaan.

\section{Good Corporate Governance}

Al-Ghanmdi dan Rhodes (2015) menyatakan bahwa good corporate governance adalah istilah yang sering digunakan untuk menjelaskan proses dan sruktur yang digunakan untuk mengarahkan dan mengelola kegiatan usaha perusahaan dalam rangka meningkatkan kekayaan pemegang saham.

\section{Ukuran Perusahaan}

Ukuran perusahaan Ukuran perusahaan diukur dengan menggunakan Log (Total Asset) karena nilai Total asset diangap mampu menggambarkan ukuran suatu perusahaan (Lestari, 2016).

\section{Kerangka Pikir}

Berdasarkan landasan teori diatas maka dapat digambarkan kerangka pikir sebagai berikut: 


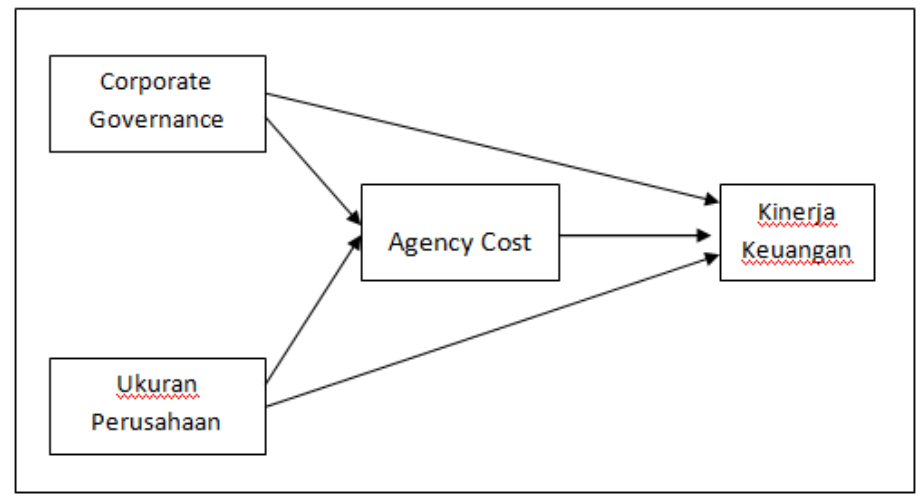

Gambar 1. Kerangka Berpikir

\section{METODE PENELITIAN}

\section{Desain Penelitian}

Menurut Sugiyono (2017) desain penelitian adalah cara ilmiah untuk mendapatkan data dengan tujuan dan kegunaan tertentu. Penelitian ini merupakan penelitian kuantitatif dimana yang digunakan merupakan data sekunder yang berasal dari laporan keuangan tahunan perusahaan manufaktur yang terdaftar dalam Bursa Efek Indonesia.

\section{Variabel penelitian}

\section{Variabel Independen}

\section{a. Good Corporate Governance}

Skala yang digunakan dalam variabel ini adalah rasio Dewan Komisaris

Komisaris independen bertujuan untuk penyeimbang pengambilan keputusan dewan komisaris. Proporsi dewan komisaris harus sedemikian rupa sehingga memungkinkan pengambilan keputusan yang efektif, tepat dan cepat serta dapat bertindak secara independen, pengukuran proporsi dewan komisaris independen sebbgai berikut :

Proporsi dewan komisaris independen :

$$
\frac{\text { Jumlah komisaris independen }}{\text { jumlah seluruh komisaris }} \times 100 \%
$$

\section{b. Ukuran Perusahaan}

Pengukuran ukuran perusahaan dalam penelitian ini menggunakan logaritma naturaldari total aset. Adapun rumus yang digunakan adalah sebagai berikut:

$$
\text { Size }=\text { LnTotalAsset }
$$

\section{Variabel Dependen}

\section{Kinerja Keuangan}

Variabel dependen dalam penelitian ini adalah kinerja keuangan. Menurut Fahmi (2015:239) “ kinerja keuangan adalah suatu analisis yang dilakukan untuk 
sejauh mana suatu perusahaan telah melaksanakan dengan aturam-aturan pelaksanaan keuangan secara baik dan benar

Berikut adalah rumus kinerja keuangan yang diukur dengan menggunakan ROA dengan rumus :

$$
R O A=\frac{\text { laba bersih setelah pajak }}{\text { total aset }} \times 100 \%
$$

\section{Variable Intervening}

Proksi agency cost yang digunakan yaitu rasio discretionary expense, yang merupakan beban yang dikeluarkan berdasarkan kebijaksanaan seorang manajer. Beban ini meliputi beban operasi, beban non operasi, beban bungan, serta gaji dan upah. Rumusnya sebagai berikut :

$$
\mathrm{AG}=\frac{\text { discretion ary expense }}{\text { penjualan bersih }}
$$

\section{Populasi, Sampel dan Sumber Data}

\section{a. Populasi}

Populasi yang digunakan dalam penelitian ini adalah perusahaan manufaktur yang terdaftar di Bursa Efek Indonesia yang menyajikan laporan keuangan secara lengkap dan publikasikan dalam annual report pada Bursa Efek Indonesia periode 2014-2018. Populasi ini berjumlah 168 perusahaan.

\section{b. Sampel}

Sampel adalah bagian dari jumlah karakteristik yang dimiliki oleh populasi yang digunakan untuk penelitian (Sugiyono, 2015).

\section{Tabel 1. Prosedur Pengambilan Sampel}

\begin{tabular}{|l|c|c|}
\hline \multicolumn{1}{|c|}{ Keterangan } & Jumlah & $(\%)$ \\
\hline $\begin{array}{l}\text { Jumlah perusahaan manufaktur sektor 4 aneka industri dan } \\
\text { sektor 5 industri barang konsumsi yang terdaftar di Bursa Efek } \\
\text { Indonesia sejak 2014-2018. }\end{array}$ & 85 & 100 \\
\hline $\begin{array}{l}\text { Perusahaan yang tidak menerbitkan laporan keuangan selama } \\
\text { tahun berturut-turut }\end{array}$ & $(25)$ & $(29.41)$ \\
\hline $\begin{array}{l}\text { Perusahaan yang tidak menyajikan data yang diperlukan } \\
\text { secara lengkap. }\end{array}$ & 0 & 0 \\
\hline $\begin{array}{l}\text { Perusahaan yang mengalami kerugian dalam periode } \\
\text { penelitian }\end{array}$ & $(13)$ & $(15.29)$ \\
\hline Tidak menyajikan laporan keuangan dalam satuan rupiah. & $(13)$ & $(15.29)$ \\
\hline Jumlah perusahaan yang memenuhi syarat. & 34 & 40.01 \\
\hline
\end{tabular}

OSumber : Hasil Pengumpulan Data

\section{HASIL DAN PEMBAHASAN}

\section{Uji Analisis Deskriptif}

Statistik deskriptif dalam penelitian ini digunakan untuk memberikan informasi mengenai variabel-variabel penelitian seperti Agency Cost (Y1), ROA (Y2), GCG (X1), dan 
UP (X2). Disamping itu, tujuan dari hasil uji statistik deskriptif ini adalah untuk melihat kualitas data penelitian yang ditujukan dengan angka atau nilai yang terdapat pada mean dan standar deviasi. Dapat dikatakan jika mean lebih besar daripada standar deviasi atau penyimpangan maka kualitas data adalah lebih baik.

Statistik deskriptif untuk variabel-variabel penelitian tersebut dapat kita lihat sebagai berikut :

\section{Tabel 2. Prosedur Pengambilan Sampel}

\begin{tabular}{|l|r|r|r|r|r|}
\hline & N & Minimum & Maximum & Mean & Std. Deviation \\
\hline ROA_Y2 & 170 & .04 & 42.13 & 11.4637 & 9.94699 \\
AC_Y1 & 170 & .03 & .49 & .2063 & .11766 \\
GCG_X1 & 170 & .00 & .88 & .3906 & .18149 \\
UP_X2 & 170 & .00 & 11.49 & 1.5481 & 3.16725 \\
ValidN (listyise) & 170 & & & & \\
\hline
\end{tabular}

Sumber : Output SPSS 22 data sekunder

Variabel ROA dengan jumlah data (N) sebanyak 170 (tahun 2014-2018), memiliki nilai minimum 0.04 dan nilai maksimum 42.13. Nilai rata-rata (mean) sebesar 11.4637 dan standar deviasi 9.94699.

Variabel AC (Agency Cost) dengan jumlah data (N) sebanyak 170 (tahun 2014-2018), memiliki nilai minimum 0.03 dan nilai maksimum 0.49 . Nilai rata-rata (mean) sebesar 0.2063 dan standar deviasi 0.11766 .

Variabel GCG (Mekanisme Corporate Governance) dengan jumlah data (N) sebanyak 170 (tahun 2014-2018), memiliki nilai minimum 0.00 dan nilai maksimum 0.88 . Nilai ratarata (mean) sebesar 0.3906 dan standar deviasi 0.18149 .

Variabel UP (Ukuran Perusahaan) dengan jumlah data (N) sebanyak 170 (tahun 20142018), memiliki nilai minimum 0.00 dan nilai maksimum 11.49. Nilai rata-rata (mean) sebesar 1.5481 dan standar deviasi 3.16725.

\section{Test Outlier}

Test outlier merupakan suatu test yang digunakan untuk mendeteksi adanya suatu data yang menyimpang terlalu jauh dari data yang lainnya dalam suatu rangkaian data (data outlier). Adanya data outlier dalam suatu rangkaian data akan membuat analisis terhadap serangkaian data menjadi bias atau tidak mencerminkan fenomena yang sebenarnya.

Salah satu cara untuk mendeteksikan adanya outlier pada masing-masing variabel penelitian adalah dengan metode Grubbs test. Dalam metode ini akan membandingkan nilai $\mathrm{Z}$ dengan critical value of $\mathrm{Z}$ dengan tingkat signifikansi 5\%. Apabila $\mathrm{Z}>\mathrm{Z}_{\text {critical maka }}$ hipotesis nul diterima atau adanya outlier yang terdeteksi. Untuk nilai Zcritical telah diberikan oleh tabel statistik berdasarkan jumlah observasi, jumlah observasi 34 perusahaan sampel dari tahun 2013- 2017 adalah 170 observasi. Nilai Zcritical dari 170 observasi adalah 2.96531404639. Sedangkan untuk mencari nilai $\mathrm{Z}$ dapat menggunakan bantuan aplikasi outlier calculator dalam situs GrapPad software.

\section{Hasil Uji Asumsi Klasik}




\section{Uji Normalitas}

Uji normalitas bertujuan untuk mengetahui apakah dalam model residual berdristibusi normal atau tidak. Metode pengujian menggunakan Uji grafik dan untuk perhitungannya menggunakan program IBM SPSS Statistic 22. Hasil uji normalitas pada penelitian ini disajikan pada gambar:

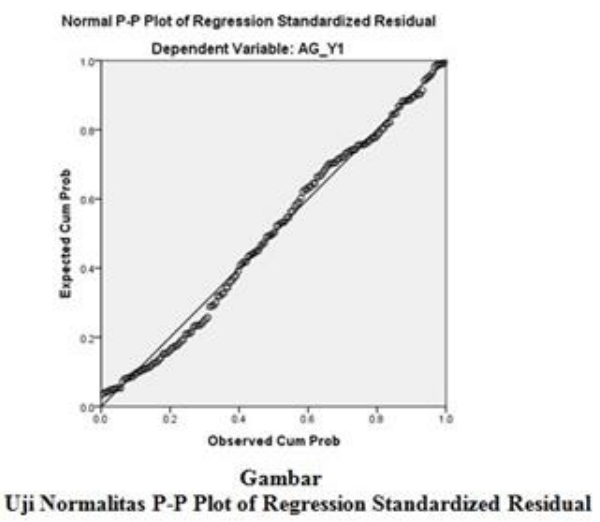

Berdasarkan hasil uji Grafik Normal P-P Plot Regression Standardized pada gambar terlihat bahwa titik-titik menyebar pada garis diagonal. Oleh karena itu berdasarkan uji normalitas, analisis regresi layak digunakan.

\section{Hasil Analisis Regresi Data Panel}

Analisis regresi linear berganda digunakan untuk mengetahui pengaruh atau hubungan secara linear antara dua atau lebih variabel independen dengan satu variabel dependen.

a. Pengujian substruktur pertama Mekanisme Corporate Governance (X1), dan Ukuran Perusahaan (X2) terhadap Agency Cost (Y1)

\section{Tabel 3. Regresi Linear Berganda}

\begin{tabular}{|c|c|c|c|c|c|c|}
\hline \multirow{2}{*}{\multicolumn{2}{|c|}{ Model }} & \multicolumn{2}{|c|}{ Unstandardized Coefficients } & \multirow{2}{*}{$\begin{array}{c}\text { Standardized } \\
\text { Coefficients } \\
\text { Beta } \\
\end{array}$} & \multirow[b]{2}{*}{$t$} & \multirow[b]{2}{*}{ Sig. } \\
\hline & & B & Std. Error & & & \\
\hline \multirow[t]{3}{*}{1} & (Constant) & 297 & .022 & & 13.693 & .000 \\
\hline & $\mathrm{GCG} \times 1$ & -189 & .048 & -.291 & -3.952 & .000 \\
\hline & $U P_{-} \times 2$ & -011 & .003 & -.303 & $-4,110$ & .000 \\
\hline
\end{tabular}

a. Dependent Variable:AG_Y1

Berdasarkan model estimasi yang terpilih, diperoleh persamaan model regresi data panel sebagai berikut :

$$
\mathrm{AC}=-0,291 \mathrm{GCG}-0,303 \mathrm{UP}+\mathrm{et}
$$

1. Koefisien regresi variabel Mekanisme Corporate Governance sebesar -0,291 artinya jika Mekanisme Corporate Governance mengalami kenaikan 1\% maka Agency Cost akan mengalami penurunan sebesar 0,291 dengan asumsi variabel independen lainnya bernilai nol atau diabaikan.

2. Koefisien variabel Ukuran Perusahaan sebesar $-0,303$ artinya jika Ukuran Perusahaan mengalami kenaikan $1 \%$ maka Agency Cost akan mengalami 
penurunan sebesar 0,303 dengan asumsi variabel independen lainnya bernilai nol atau diabaikan.

b. Pengujian kedua Mekanise Corporate Governance (X1), Ukuran Perusahaan (X2), dan Agency Cost (Y1) terhadap Kinerja Perusahaan (Y2)

c.

Tabel 4. Regresi Linear Berganda

\begin{tabular}{|c|c|c|c|c|c|c|}
\hline \multirow{2}{*}{\multicolumn{2}{|c|}{ Model }} & \multicolumn{2}{|c|}{ Unstandardized Coefricients } & \multirow{2}{*}{$\begin{array}{c}\text { Standardized } \\
\text { Coefficients } \\
\text { Beta } \\
\end{array}$} & \multirow[b]{2}{*}{$\mathrm{t}$} & \multirow[b]{2}{*}{ Sig. } \\
\hline & & $\mathbf{B}$ & Std. Error & & & \\
\hline 1 & $\begin{array}{l}\text { (Constant) } \\
\mathrm{AC} \text { _logr1 } \\
\mathrm{GCG} \times 1 \\
\text { UP_logX2 }\end{array}$ & $\begin{array}{r}14.979 \\
.550 \\
-11.558 \\
1.020\end{array}$ & $\begin{array}{r}2.127 \\
2.712 \\
4.930 \\
623\end{array}$ & $\begin{array}{r}.028 \\
-.303 \\
.193\end{array}$ & $\begin{array}{r}7.041 \\
.203 \\
-2.344 \\
1.639\end{array}$ & $\begin{array}{l}.000 \\
.840 \\
.022 \\
106\end{array}$ \\
\hline
\end{tabular}

Berdasarkan model estimasi yang terpilih, diperoleh persamaan model regresi data panel sebagai berikut :

$$
\mathrm{ROA}=-0,303 \mathrm{GCG}+0,193 \mathrm{UP}+0,028 \mathrm{AG}+\text { et }
$$

1. Koefisien regresi variabel Agency Cost sebesar 0,028 artinya jika Agency Cost mengalami kenaikan $1 \%$ maka Kinerja Perusahaan akan mengalami penambahan sebesar 0,028 dengan asumsi variabel independen lainnya bernilai nol atau diabaikan.

2. Koefisien regresi variabel Mekanisme Corporate Governance -0,303 artinya jika Mekanisme Corporate Governance mengalami kenaikan 1\% maka Kinerja Perusahaan akan mengalami penurunan sebesar 0,303 dengan asumsi variabel independen lainnya bernilai nol atau diabaikan.

3. Koefisien regresi variabel Ukuran Perusahaan 0,193 artinya jika Ukuran Perusahaan mengalami kenaikan $1 \%$ maka Kinerja Perusahaan akan mengalami peningkatan sebesar 0,193 dengan asumsi variabel independen lainnya bernilai nol atau diabaikan.

\section{Perhitungan Analisis Jalur}

Untuk menguji pengaruh variabel intervening digunakan metode analisis jalur (Path Analysis). Besarnya pengaruh langsung dapat dilihat langsung pada nilai koefisien regresi, sedangkan besarnya pengaruh tidak langsung dihitung dengan mengalikan koefisien tidak langsungnya.

a. Pengaruh Langsung (Direct Effect atau DE)

1. Pengaruh Mekanisme Corporate Governance terhadap agency cost sebesar 0,291

2. Pengaruh Ukuran Perusahaan terhadap agency cost sebesar $-0,303$

3. Pengaruh Mekanisme Corporate Governance terhadap kinerja perusahaan sebesar $-0,303$

4. Pengaruh Ukuran Perusahaan terhadap kinerja perusahaan sebesar 0,193

5. Pengaruh agency cost terhadap kinerja perusahaan sebesar 0,028

b. Pengaruh tidak langsung (Indirect Effect)

1. Mekanisme Corporate Governance terhadap kinerja perusahaan melalui 
agency cost sebesar

$(-0,291 \times 0,028)-0,008148$

2. Ukuran Perusahaan terhadap kinerja perusahaan melalui agency cost sebesar ($0,303 \times 0,028)-0,008484$

c. Pengaruh Total (Total Effect)

1. Mekanisme Corporate Governance terhadap kinerja perusahaan melalui agency cost sebesar

$[-0,303+(-0,291 \times 0,028)]-0,311148$

2. Ukuran Perusahaan terhadap kinerja perusahaan melalui agency cost sebesar [ $0,193+(-0,303 \times 0,028)] 0,184516$

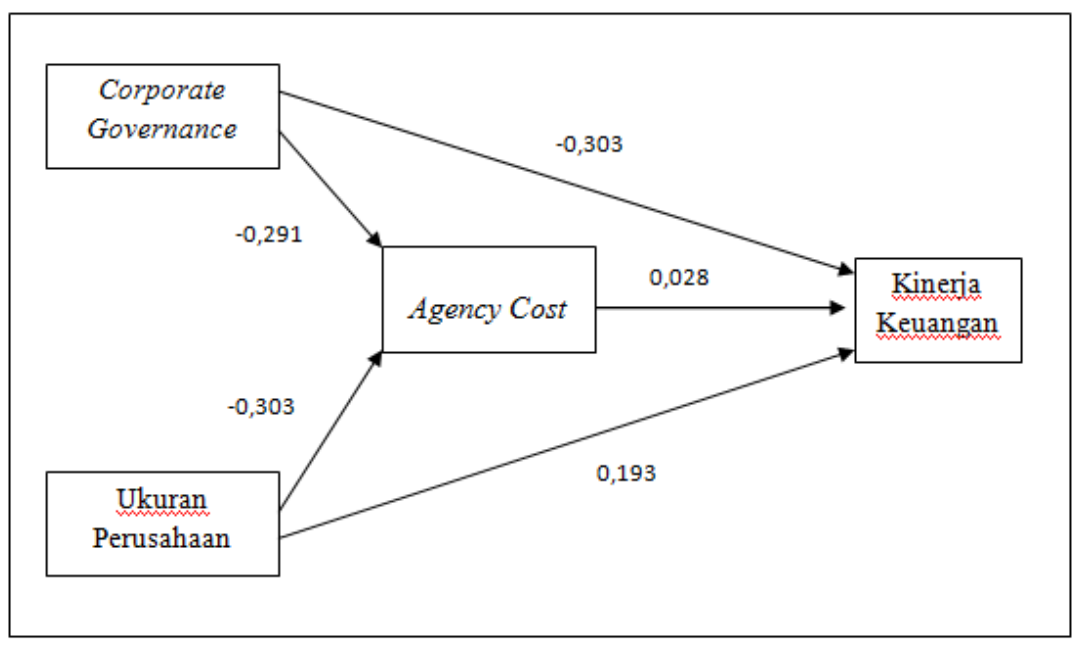

Gambar 2. Analisis Jalur

Dari gambar diatas dapat diartikan jika pengaruh langsung Mekanisme Corporate Governance terhadap kinerja perusahaan lebih besar dari pengaruh tidak langsung Mekanisme Corporate Governance terhadap kinerja perusahaan (-0,303 > - 0,008148)

Jadi dapat diartikan jika pengaruh langsung Ukuran Perusahaan terhadap kinerja perusahaan lebih besar dari pengaruh tidak langsung Ukuran Perusahaan terhadap kinerja perusahaan $(0,193>-0,008484)$

\section{Hasil Uji Hipotesa}

\section{Hasil Pengujian Hipotesis Secara Simultan (Uji F)}

Hasil uji F dapat dilihat pada tabel dibawah ini :

a. Pengujian substruktur pertama Mekanisme Corporate Governance (X1), dan Ukuran Perusahaan (X2) secara bersama-sama terhadap Agency Cost (Y1). 
Tabel 5. Regresi Linear Berganda

\begin{tabular}{|ll|r|r|r|r|r|}
\hline Model & & Sum of Squares & Df & Mean Square & F & Sig. \\
\hline 1 & Regression & .322 & 2 & .161 & 13.327 & $.000^{\circ}$ \\
& Residual & 2.018 & 167 & .012 & & \\
& Total & 2.340 & 169 & & & \\
\hline
\end{tabular}

a. Dependent Variable: $A G_{-} Y 1$

b. Predictors: (Constant), UP_X2, GCG_X1

Berdasarkan tabel diatas menunjukan hasil dari Uji $\mathrm{F}$ yaitu $\mathrm{F}$ hitung lebih besar dari F tabel dengan nilai sebesar $13,327>3,05$. Selain itu, dapat dilihat nilai probabilitas signifikansi sebesar 0,000 atau lebih kecil dari 0,05 $(0,000<0,05)$. Hal ini menunjukan bahwa variabel Mekanisme Corporate Governance dan Ukuran Perusahaan secara bersamasama berpengaruh positif signifikan terhadap agency cost.

b. Pengujian kedua Mekanisme Corporate Governance (X1), Ukuran Perusahaan (X2) dan Agency Cost (Y1) secara bersama-sama terhadap Kinerja Perusahaan

Tabel 6. Uji F

\begin{tabular}{|ll|r|r|r|r|r|}
\hline Model & & Sum of Squares & \multicolumn{1}{|c|}{ Df } & Mean Square & F & Sig. \\
\hline 1 & Regression & 331.548 & 3 & 110.516 & 3.962 & $.011^{\circ}$ \\
& Residual & 2036.351 & 73 & 27.895 & & \\
& Total & 2367.899 & 76 & & & \\
\hline
\end{tabular}

a. Dependent Variable:ROA_r2

b. Predictors: (Constant), UP_logX2, GCG_X1, AC_logr1

Berdasarkan tabel diatas menunjukan hasil dari Uji $\mathrm{F}$ yaitu $\mathrm{F}$ hitung lebih besar dari F tabel dengan nilai sebesar 3,962>2,66. Selain itu, dapat dilihat nilai probabilitas signifikansi sebesar 0,011 atau lebih kecil dari 0,05 $(0,011<0,05)$. Hal ini menunjukan bahwa variabel Mekanisme Corporate Governance, Ukuran Perusahaan dan Agency Cost (Y1) secara bersama-sama berpengaruh positif signifikan terhadap kinerja perusahaan.

\section{Hasil Pengujian Hipotesis Secara Parsial (Uji t)}

Hasil uji t dapat dilihat pada tabel dibawah ini :

\section{a. Hasil analisis regresi untuk pengujian substruktur 1}

1. Pengaruh Mekanisme Corporate Governance terhadap agency cost

Pengaruh Mekanisme Corporate Governance terhadap agency cost pengujian hipotesis dengan menggunakan uji signifikansi dapat dilakukan dengan membandingkan $\mathrm{t}$ hitung dengan $\mathrm{t}$ tabel atau dengan membandingkan nilai probabilitas signifikansi sebesar 0,05. Berdasarkan tabel, dapat dilihat nilai t hitung sebesar $-3,952$ sedangkan $t$ tabel pada signifikansi 0,05 sebesar 1,65408 sehingga $t$ hitung $<\mathrm{t}$ tabel $(3,952>$ 1,65408). Selain itu dapat dilihat nilai probabilitas signifikansi sebesar 0,000 atau kecil dari 0,05 $(0,000<0,05)$ Ho ditolak dan $\mathrm{H1}$ diterima. Berdasarkan hasil uji hipotesis diatas, dapat disimpulkan bahwa variabel Mekanisme Corporate Governance berpengaruh negatif terhadap agency cost.

2. Pengaruh Ukuran Perusahaan terhadap agency cost

Pengujian hipotesis dengan menggunakan uji signifikansi dapat dilakukan dengan membandingkan $t$ hitung dengan $t$ tabel atau dengan membandingkan nilai probabilitas 
signifikansi sebesar 0,05. Berdasarkan t tabel, dapat dilihat nilai t hitung sebesar $-4,110$ sedangkan t tabel pada signifikansi 0,05 sebesar 1,65408 sehingga $t$ hitung $<\mathrm{t}$ tabel ($4,110<1,65408)$. Selain itu, dapat dilihat nilai probabilitas signifikansi sebesar 0,000 atau lebih kecil dari $0,05(0,000<0,05)$ Ho ditolak dan $\mathbf{H 2}$ diterima. Berdasarkan hasil uji hipotesis diatas, dapat disimpulkan bahwa variabel Ukuran Perusahaan berpengaruh negatif terhadap agency cost.

\section{b. Hasil analisis regresi untuk pengujian substruktur 2}

1. Pengaruh Mekanisme Corporate Governance terhadap kinerja perusahaan

Pengujian hipotesis dengan menggunakan uji signifikansi dapat dilakukan dengan membandingkan $t$ hitung dengan $t$ tabel atau dengan membandingkan nilai probabilitas signifikansi sebesar 0,05. Berdasarkan t tabel, dapat dilihat nilai t hitung sebesar -2,344 sedangkan $t$ tabel pada signifikansi 0,05 sebesar 1,65408 sehingga $t$ hitung $<t$ tabel ($2,344<1,65408)$. Selain itu, dapat dilihat nilai probabilitas signifikansi sebesar 0,022 atau lebih kecil dari $0,05(0,022<0,05)$ Ho ditolak dan $\mathbf{H 3}$ diterima. Berdasarkan hasil uji hipotesis diatas, dapat disimpulkan bahwa variabel Mekanisme Corporate Governance berpengaruh negatif terhadap kinerja perusahaan.

2. Pengaruh Ukuran Perusahaan terhadap kinerja perusahaan

Pengujian hipotesis dengan menggunakan uji signifikansi dapat dilakukan dengan membandingkan $t$ hitung dengan $t$ tabel atau dengan membandingkan nilai probabilitas signifikansi sebesar 0,05. Berdasarkan t tabel, dapat dilihat nilai t hitung sebesar 1,639 sedangkan $\mathrm{t}$ tabel pada signifikansi 0,05 sebesar 1,65408 sehingga $\mathrm{t}$ hitung $<\mathrm{t}$ tabel $(1,639<1,65408)$. Selain itu, dapat dilihat nilai probabilitas signifikansi sebesar 0,106 atau lebih besar dari $0,05(0,106>0,05)$ Ho diterima dan $\mathbf{H 4}$ ditolak. Berdasarkan hasil uji hipotesis diatas, dapat disimpulkan bahwa variabel Ukuran Perusahaan tidak berpengaruh positif terhadap kinerja perusahaan.

3. Pengaruh agency cost terhadap kinerja perusahaan

Pengujian hipotesis dengan menggunakan uji signifikansi dapat dilakukan dengan membandingkan $t$ hitung dengan $t$ tabel atau dengan membandingkan nilai probabilitas signifikansi sebesar 0,05. Berdasarkan t tabel, dapat dilihat nilai t hitung sebesar 0,203 sedangkan t tabel pada signifikansi 0,05 sebesar 1,65408 sehingga $t$ hitung $<\mathrm{t}$ tabel $(0,203<1,65408)$. Selain itu, dapat dilihat nilai probabilitas signifikansi sebesar 0,840 atau lebih besar dari 0,05 $(0,840>0,05)$ Ho diterima dan $\mathbf{H 5}$ ditolak. Berdasarkan hasil uji hipotesis diatas, dapat disimpulkan bahwa variabel agency cost tidak berpengaruh negatif terhadap kinerja perusahaan.

\section{Hasil Pengujian Koefisien Determinasi $\left(\mathbf{R}^{2}\right)$}

Hasil uji koefisien determinasi dapat dilihat pada tabel dibawah ini :

a. Pengujian substruktur pertama Mekanisme Corporate Governance (X1), dan Ukuran Perusahaan (X2) terhadap Agency Cost (Y1). 
Tabel 7. Koefisien Determinasi

Model Summary

\begin{tabular}{|l|r|r|r|c|}
\hline Model & R & R Square & \multicolumn{1}{|c|}{$\begin{array}{c}\text { Adjusted R } \\
\text { Square }\end{array}$} & $\begin{array}{c}\text { Std. Error of the } \\
\text { Estimate }\end{array}$ \\
\hline 1 & $.371^{3}$ & .138 & .127 & .10991 \\
\hline
\end{tabular}

a. Predictors: (Constant), UP_X2, GCG_X1

Dari tabel diatas, karena variabel bebas lebih dari satu, maka dapat kita lihat pada kolom $R$ Square $=0,138$ atau $13,8 \%$. Hal ini berarti bahwa $13,8 \%$ agency cost dapat dijelaskan oleh variasi variabel independen yaitu Mekanisme Corporate Governance (X1) dan Ukuran Perusahaan (X2) sisanya sebesar 86,2\% (100\% - 13,8\%) dijelaskan oleh sebab-sebab lain diluar model.

b. Pengujian kedua Mekanisme Corporate Governance (X1), Ukuran Perusahaan (X2) dan Agency Cost (Y1) terhadap Kinerja Perusahaan (Y2)

\section{Tabel 8. Nilai R2}

Model Summary

\begin{tabular}{|l|r|r|r|r|}
\hline Model & R & R Square & \multicolumn{1}{c|}{$\begin{array}{c}\text { Adjusted R } \\
\text { Square }\end{array}$} & $\begin{array}{c}\text { Std. Error of the } \\
\text { Estimate }\end{array}$ \\
\hline 1 & $.374^{3}$ & .140 & .105 & 5.28159 \\
\hline
\end{tabular}

a. Predictors: (Constant), UP_logX2, GCG_X1, AC_logY1

Dari tabel diatas, karena variabel bebas lebih dari satu, maka dapat kita lihat pada kolom $R$ Square $=0,140$ atau 14\%. Hal ini berarti bahwa $14 \%$ kinerja perusahaan dapat dijelaskan oleh variasi variabel independen yaitu Mekanisme Corporate Governance (X1), Ukuran Perusahaan (X2) dan Agency Cost (Y1), sisanya sebesar 86\% (100\% - 14\%) dijelaskan oleh sebab-sebab lain diluar model.

\section{KESIMPULAN DAN SARAN}

Berdasarkan hasil penelitian yang telah dilakukan pada bab sebelumnya maka dapat disimpulkan sebagai berikut:

1. Mekanisme Corporate Governance berpengaruh negatif signifikan terhadap agency cost pada perusahaan manufaktur yang terdaftar di Bursa Efek Indonesia pada tahun 2014-2018.

2. Ukuran Perusahaan berpengaruh negatif signifikan terhadap agency cost pada perusahaan manufaktur yang terdaftar di Bursa Efek Indonesia pada tahun 20142018.

3. Mekanisme Corporate Governance berpengaruh negatif signifikan terhadap kinerja perusahaan pada perusahaan manufaktur yang terdaftar di Bursa Efek Indonesia pada tahun 2014-2018.

4. Ukuran Perusahaan tidak berpengaruh positif signifikan terhadap kinerja perusahaan pada perusahaan yang terdaftar di Bursa Efek Indonesia pada tahun 2014-2018.

5. Agency cost tidak berpengaruh positif signifikan terhadap kinerja perusahaan pada perusahaan manufaktur yang terdaftar di Bursa Efek Indonesia pada tahun 2014- 

2018.

6. Secara tidak langsung Mekanisme Corporate Governance melalui agency cost mempunyai pengaruh terhadap kinerja perusahaan.

7. Secara tidak langsung Ukuran Perusahaan melalui agency cost mempunyai pengaruh terhadap kinerja perusahaan.

\section{DAFTAR RUJUKAN}

Alabdullah, Tariq Tawfeeq Yousif.2018. "The Relationship Between Ownership Structure adn Firm Financial Performance”. Benchmarking An International Journal Vol.25 No.1, 2018.

Alamsya, Agus rahman dan Muchlas, Zainul.2017.Pengaruh Agency cost Terhadap Kinerja Keuangan Perusahaan Keluarga Menggunakan Tobin's $Q$ dan Almant ZScore”.Jurnal JIBEKA Vol.11 No.1, 2017.

Aprina, Desi. 2014. "Pengaruh Kepemilikan Manajerial, Kepemilikan Institusional dan Ukuran Perusahaan Terhadap Kinerja Perusahaan Yang Diukur Menggunakan Economic Value Added". Jurnal Akuntansi.

Dawar, Varun. "Agency Theory, Capital Structure and Firm Performance : Some Indian Evidance." Managerial Finance, Vol. 40 No.12, 2014.

Efendi, Azzalia Feronicha Wianta dan Wibowo, Seto Sulaksono Adi. 2017. "Pengaruh Debt To Equity Ratio (DER) dan Debt To Asset Ratio (DAR) Terhadap Kinerja Perusahaan Di Sektor Keuangan Yang Terdaftar Di Bursa Efek Indonesia”. Jurnal Akuntansi.

Fachrudin, Khaira Amalia. 2011. "Analisis Pengaruh Struktur Modal, Ukuran Perusahaan, dan Agency Cost Terhadap Kinerja Perusahaan". Jurnal Akuntansi dan Keuangan Vol.13 No 1 Mei 2011: 37-46

Fahmi, Irham. 2014. Analisis Laporan Keuangan. Bandung : Alfabeta. Hery . 2015. Analisis Laporan Keuangan. Jakarta : Bumi Aksara.

Iswadi dan Yowanda, Nonie Carmila. 2018. "Pengaruh Kompensasi Direksi, Struktur Modal, dan Diversifikasi Terhadap Kinerja Perusahaan”. Jurnal Kebangsaan, Vol.7 No.14 Juli- Desember 2018.

Jensen, Meckling.1976."Theory of The Firm: Managerial Behavior, Agency Cost and Ownership Structure and Ownership Structure". Jourmal of Financial Economic.

Khan, et al.2012."Impact of Firm Capital Structure decision on Debt Agency problem: Evicance for Pakistan”. Journal of Basic and Applied Scientific Research.

Mahdi,Adnan dan Mujahidin.2014.Panduan Penelitian Praktis Untuk Menyusun Skripsi,Tesis,Disertasi.Bandung : ALFABETA.

Mardnly, dkk. "Corpotate Governance and Firm Performance : An Emperical Evidence From Syria. International Jorunal of Islamic and Middle Fastern Finance and Management Vol. 11, No. 4, 2018.

Narbuko, Cholid dan Abu Achmadi. 2013. Metodologi Penelitian. Jakarta : PT. Bumi Aksara. Putra. 2017. "Analisis Pengaruh Kepemilikan Institusiona dan Kepemilikan Manajerial Terhadap Kinerja dan Nilai Perusahaan”. Studi Akuntansi \& Keuangan Indonesia.

Putri, Tyara Dwi. 2017. "Pengaruh Struktur Kepemilikan dan Struktur Modal Terhadap Agency Cost”. Menara Ekonomi ISSN: 2407-8565 Volume III No.6 - Oktober 2017. 
Rani, Puspita.2015."Peran Kepemilikan Manajerial Dalam Memoderasi Pengaruh Strategi Diversifikasi Terhadap Kinerja Perusahaan”. Jurnal Akuntansi dan Keuangan Vol.4 No.2, 2015

Riadi, Edi. 2016. Statistik Penelitian. Yogyakarta: ANDI.

Sari, Fitriana Warap. 2015. "Pengaruh Struktur Kepemilikan Terhadap Kinerja Perusahaan Dengan Struktur Modal Sebafai Pemoderasi”. Jurnal Ilmu \& Riset Akuntansi Vol.4 No.8 2015.

Sanjaya, William.2017."Faktor-faktor Yang Mempengaruhi Kinerja Perusahan Pada Perusahaan Yang Terdaftar Di Bursa Efek Indonesia”.Jurnal Bisnis dan Akuntansi.

Sudana, I Made. 2011. Manajemen Keuangan Perusahaan Teori \& Praktik. Jakarta : ERLANGGA

Sugiarto. 2017. Metode Penelitian Bisnis. Yogyakarta : ANDI.

Sugiyono. 2016. Metode Penelitian Kuantitatif, Kualitatif dan R\&D. Bandung : Alfabeta. Sukandarrumi dan Haryanto. 2014. Dasar-dasar Penulisan Proposal Penelitian. Yogyakarta : Gadjah Mada University Press.

Sunyoto,Danang.2016.Metodologi Penelitian Ekonomi. Yogyakarta: CAPS.

Syafruddin.2006. “Analisis Faktor Yang Mempengaruhi Kinerja Perusahaan”.Jurnal Akuntansi.

Tse, Chin Bun dan Rodgers, Timothy. "The Capital Structure of Chinese Listed Firms:is Manufacturing Industry Special”. Managerial Finance Vol.40 No5, 2014.

Utari, Desi. 2016. “Analisis Pengaruh Struktur Kepemilikan Saham Terhadap Kinerja Perusahaan".Skripsi Fakultas Ekonomi Universitas Putra Indonesia.

Widyati, Maria Fransisca. "Pengaruh Dewan Direksi, Komisaris Independen, Komite Audit, Kepemilikan Manajerial dan Kepemilikan Institusional Terhadap Kinerja Keuangan”. Jurnal Ilmu Manajemen Vol.1 No.1, 2013.

Zouari, Sarra Ben Slaman dan Taktak, Neila Boulila.2014.”Ownership and Financial Performance in Islamic Banks". International Journal of Islamic and Middle Eastern Finance and Management Vol.7 No.2, 2014.

Situs :

www.sahamok.com

$\underline{\text { www.idx.co.id }}$ 